\title{
ACUPUNCTURE PALPATION DIAGNOSIS IN PREPURCHASE EVALUATION OF HORSES
}

\author{
Palpação Diagnóstica por Acupuntura na Avaliação Pré-compra de Cavalos
}

\section{Pedro Vicente Michelotto Júnior}

Médico Veterinário, M. Sc., Prof. da PUCPR, Curitiba - PR. e-mail: michelottojunior@yahoo.com.br

Daiane Xavier Rego

Graduanda de Medicina Veterinária da PUCPR, São José dos Pinhais - PR. e-mail: dai_vet@hotmail.com

Peterson Triches Dornbusch

Médico Veterinário, Dr., Prof. da PUCPR, Curitiba - PR. e-mail: petriches@gmail.com

\begin{abstract}
The purchase evaluation of 23 horses was conducted and the physical examination was done using the Western methods for examination of the Musculoskeletal System, and the Chinese Acupuncture Palpation Diagnosis. There was a $52.17 \%$ diagnostic agreement. Considering some different diagnoses as a result of the differences in interpreting the obtained signs, and having both methods used by an experienced practitioner in a complementary way, the confidence for resulting in a clear clinical condition of the evaluated horses would be $86.96 \%$.
\end{abstract}

Keywords: Acupuncture; Prepurchase evaluation; Horses; Musculoskeletal system; Traditional Chinese Medicine.

\section{Resumo}

A avaliação para compra de 23 cavalos foi procedida e o exame físico conduzido pelos métodos ocidentais para exame do sistema musculoesquelético e da palpação diagnóstica dos pontos de acupuntura. Houve uma concordância no diagnóstico em 52,17\% dos casos. Considerando diferenças entre os métodos diagnósticos em função das diferenças na interpretação dos sinais clínicos e tendo sido ambos os métodos utilizados de forma complementar, por um profissional experiente, um resultado mais completo com relação à condição clínica do cavalo examinado foi obtido em $86,96 \%$ das vezes.

Palavras-chave: Acupuntura; Avaliação pré-compra; Cavalos; Sistema musculoesquelético; Medicina Tradicional Chinesa. 


\section{INTRODUCTION}

The assessment of a horse's health state prior to purchase is a service frequently requested of the equine practitioner. It is a very important service to the equine business. Horses must be bought and sold for the business to progress (BEEMAN; SOULE; SWANSON, 1992). The purchase examination has become increasingly complex in recent years, especially for private sales, because clients generally expect a secure investment when purchasing a horse (HAWKINS, 1999). Although the procedures used in public sale purchases have changed to some degree, they still are constrained by the wishes of the consignors and sales company in the environment of the public sales barn (HAWKINS, 1999). The horse's reputation in a specific community may be affected by the examination results. Therefore, the examination must always be done in a very methodic, effective, and professional manner to provide the information necessary for the purchaser. This will go a long way in avoiding problems ranging from unhappy clients to legal action. The reasons for examining the health state of the horse being considered for purchase are to identify existing problems and any potential for future problems and to interpret results of the examination relevant to the horse's intended use (BEEMAN; SOULE; SWANSON, 1992; ALTAMIRANO, 2001). The more strenuous or precise the activity, the more important minor infirmities may become (BEEMAN; SOULE; SWANSON, 1992). The physical examination can be considered the most important part of the purchase examination (GOBLE, 1992).

The musculoskeletal system frequently is responsible for rendering the equine athlete unsuitable for competition. This fact leads to immediate recognition of the importance of the musculoskeletal examination in the purchase evaluation of the horse. Therefore, a thorough, meticulous examination is readily justifiable, regardless of the level of athletic competition for which the individual will be used (GOBLE, 1992). A veterinarian that performs purchase examination must have good experience on lameness examination (ALTAMIRANO, 2001).

The equine practitioner must be able to perform a thorough physical examination during a purchase evaluation, including: according to Reed (1992) the nervous system; according to Fregin (1992) cardiovascular system; according to Haynes (1992) respiratory system; according to Bennett (1992) digestive system; according to Asburry (1992) reproductive system; and according to Lavach (1992).

The use of Acupuncture Palpation Diagnosis in the equine physical examination has been proposed (CAIN, 2003a; FLEMING, 2001; McCORMICK, 1997), and the integration of both acupuncture palpation diagnosis and western manipulation was demonstrated (SUTHERLAND, 1997; VONDERWELL, 1997). There are few differences between Western and Chinese medicines. Whereas Western Medicine has evolved into a system of categorization and compartmentalization, Chinese medicine looks for the thread that binds the whole (FLEMING, 2001). The second major difference would lie in the emphasis placed on the symptoms found. The information amassed by the palpation examination depends directly on the skill and experience of the practitioner. Pain at a specific point may indicate one of several possibilities. In general, arriving at an accurate diagnosis requires the presence of a consistent series of active trigger points (CAIN, 2003b; FLEMING, 2001). Cain (2003b) shows the acupuncture palpation diagnosis for the musculoskeletal system evaluation, denominating syndromes the combination of active trigger points that are considered repeatable and reliable, indicating a problem related to a specific joint or region of the musculoskeletal system.

This report intends to discuss the use of the Western physical examination of the musculoskeletal system and the acupuncture diagnostic palpation, used together in the purchase evaluation of 23 athlete horses, and its usefulness in comparison with both methods used in separate.

\section{MATERIAL AND METHODS}

The purchase examination of 23 performance horses ( 5 racehorses and 18 jumping horses) were performed at the Santa Fe Equine Clinic (Curitiba - Brazil), in the years from 2003 to 2005. The level of performance intended for the horses was variable and it was not considered in this report. 
A methodical evaluation was carried out as showed by various authors, were a thorough observation was followed by physical examination. First, the acupuncture diagnostic palpation was performed and the obtained data registered in the examination report. Following, the cardiovascular, respiratory, eye and neurological evaluations were done and a thorough musculoskeletal evaluation was finally performed. The findings obtained by the acupuncture diagnostic palpation and the western musculoskeletal system examination were compared. Musculoskeletal system evaluation has been considered normal when no painful reactions where evidenced by the horse.

All the purchase evaluations diagnostic methods (radiology, ultrasonography and airway endoscopy) was performed as indicated, but the physical examination will be the item of discussion of this paper.

\section{RESULTS}

The 23 horses were examined at the Santa Fe Equine Clinic and passed through a thorough purchase evaluation, the sequence of all evaluations being the history, observation, acupuncture diagnostic palpation and systems evaluation as well as a meticulous musculoskeletal system examination. The main problems found during the evaluations were separated by the western denomination, and are shown in table 1. There could be found 10 horses with Back Pain, 8 horses with sacroiliac region pain, 3 with pain on both hocks, 6 with pain on one hock, 3 with foot pain, one horse with pain on both front fetlocks, one with pain on the front and hind fetlocks, one presenting a dental fistula, one case of shoulder pain, one horse with a painful front superficial flexor tendon and 5 musculoskeletal evaluations were normal.

Being the acupuncture diagnostic palpation the first part of the physical examination, it could result either in a definite diagnosis or in a suggestion of a possible diagnosis or site for a problem to be investigated. The results from both the musculoskeletal system examination and the acupuncture diagnostic palpation, for the purpose of purchase examinations, are shown in TABLE 1.

Musculoskeletal System Examination and Acupuncture Diagnostic Palpation agreed on the totality of the final diagnostic condition or, on its majority, in 12/23 (52.17\%) purchasing evaluations. They were horses 2 (acupuncture pointed both front fetlocks as site of possible problem), 4, 7 (Musculoskeletal examination also evidenced front feet pain), 9, 11, 12, 15, 16, 17 (Musculoskeletal examination evidenced also pain at the left hock), 19 (Musculoskeletal examination evidenced the right hock as a site of pain and the Acupuncture palpation pointed the right front foot as a site of problem) and horse 22 (Acupuncture pointed also both stifles).

Back Pain was diagnosed in $10(1,2,5,9,14,15,16,17,18$ and 22) horses in the musculoskeletal examination. The Acupuncture Palpation could find other meanings for the painful backs, analyzing the reactive points, resulting in different suggestive diagnosis. In $6 / 9(1,2,5,9,14$ and 18) horses acupuncture palpation indicated hock problems (Hock Syndrome) and, 3 horses (1, 18 and 22) presenting signs of stifle involvement (Stifle Syndrome) (CAIN, 2003a). Two horses (14 and 15) evidenced a suggestion of digestive system impairment, because of the reactive points on their back. Nine horses ( 7 , $11,14,15,16,17,18,19$ and 22) showed problem at the sacroiliac region by the acupuncture palpation diagnosis, and 4 of them (7, 16, 17 and 22) fell in the diagnosis of Sacral Malalignments (CAIN, 2003b). These nine horses evidenced back pain, pain on palpation of the sacroiliac region or both.

Acupuncture palpation indicated mouth problem, possibly being teeth or temporomandibular joint, in 5 purchase evaluations.

Musculoskeletal examination resulted normal (no painful reactions on musculoskeletal system palpation) in 5 evaluations. Horse number 3 had an enlarged left hind fetlock, there was no sign of lameness and the joint flexion did not elicit pain, although there were radiological signs of degenerative joint disease. In this case, acupuncture palpation had indicated the diseased fetlock as a site of possible problem. Horse number 8 passed normally through the musculoskeletal system palpation although there were signs of previous use of topical blister over the flexor tendons. The acupuncture palpation pointed the distal palmar region of both front limbs as site of probable problem. Both diagnostic methods agreed about the good physical condition of horses number 12, 20 and 23. 
TABLE 1 - Diagnostic results of the Musculoskeletal Examination and of the Acupuncture Palpation Diagnosis, in 23 prepurchase evaluations

Tabela 1 - Diagnósticos do Exame do Sistema Musculo esquelético

e do Diagnóstico por Palpação de Acupontos, em 23 avaliações pré compra

\begin{tabular}{|c|c|c|c|}
\hline HORSE & ACTIVTTY & MUSCULOSKELETAL SYSTEM EXAMINATION & $\begin{array}{c}\text { ACUPUNCTURE DIAGNOSTIC } \\
\text { PALPATION }\end{array}$ \\
\hline 1 & Jumping & $\begin{array}{l}\text { Back pain, sacroiliac pain, pain in both hocks (most } \\
\text { important on the right side) and both front feet }\end{array}$ & $\begin{array}{l}\text { Mouth problem, front feet problem, } \\
\text { front fetlock problem and, right hock } \\
\text { and stifle problem }\end{array}$ \\
\hline 2 & Jumping & $\begin{array}{l}\text { Dental fistula, shoulder muscle pain, back pain, pain } \\
\text { in both hocks }\end{array}$ & $\begin{array}{l}\text { Mouth problem, shoulder problem, } \\
\text { front fetlocks problem and both } \\
\text { hocks problem }\end{array}$ \\
\hline 3 & Jumping & $\begin{array}{l}\text { No pain on musculoskeletal evaluation although } \\
\text { evidenced an augmented left hind fetlock with } \\
\text { radiological signs of degenerative joint disease }\end{array}$ & $\begin{array}{l}\text { Problem on stifle, hock and fetlock } \\
\text { joints region on the left hind limb. } \\
\text { Bony system problem }\end{array}$ \\
\hline 4 & Jumping & Pain on left hock & $\begin{array}{l}\text { Mouth problem and left hock } \\
\text { problem }\end{array}$ \\
\hline 5 & Jumping & Back pain and sacroiliac pain & $\begin{array}{l}\text { Mouth problem and left hock } \\
\text { problem }\end{array}$ \\
\hline 6 & Jumping & Pain on the left hock and left front foot & $\begin{array}{l}\text { Digestive System problem (Stomach } \\
\text { and food transformation) }\end{array}$ \\
\hline 7 & Jumping & Pain on front feet and sacroiliac pain & Sacral malalignments \\
\hline 8 & Racing & Normal musculoskeletal evaluation & $\begin{array}{l}\text { Flexor tendon problem on both sides, } \\
\text { problem on the palmar region of the } \\
\text { front limbs. Digestive System } \\
\text { problem (Stomach) }\end{array}$ \\
\hline 9 & Jumping & Back pain and pain on both hocks & Problem on both hocks. \\
\hline 10 & Jumping & $O C D$ in the left hind fetlock & $\begin{array}{l}\text { Mouth problem, left stifle problem } \\
\text { and bony system problem }\end{array}$ \\
\hline 11 & Jumping & $\begin{array}{l}\text { Painful right front Superficial flexor tendon, sacroiliac } \\
\text { pain }\end{array}$ & $\begin{array}{l}\text { Flexor tendon problem on both sides } \\
\text { and sacroiliac region problem }\end{array}$ \\
\hline 12 & Jumping & Normal musculoskeletal evaluation & Normal evaluation \\
\hline 13 & Jumping & Pain on front and hind fetlocks & Problem on the left hind fetlock. \\
\hline 14 & Jumping & Back pain and sacroiliac pain & $\begin{array}{l}\text { Problem on both hocks, sacroiliac } \\
\text { region problem. Digestive system } \\
\text { problem (Stomach) }\end{array}$ \\
\hline 15 & Jumping & Back pain & $\begin{array}{l}\text { Sacroiliac region problem. Digestive } \\
\text { system problem (Stomach and food } \\
\text { transformation) }\end{array}$ \\
\hline 16 & Jumping & Back pain and sacroiliac pain & Sacral Malalignments \\
\hline 17 & Jumping & Back pain and left hock pain & Sacral Malalignments \\
\hline 18 & Jumping & Back pain & $\begin{array}{l}\text { Sacroiliac region problem. Problem } \\
\text { on both hocks and stifles. }\end{array}$ \\
\hline 19 & Racing & Sacroiliac pain, right hock pain, front fetlocks pain & $\begin{array}{l}\text { Mouth problem. Sacroiliac region } \\
\text { problem. Problem on both front } \\
\text { fetlocks and right front foot. }\end{array}$ \\
\hline 20 & Jumping & Normal musculoskeletal evaluation & Normal evaluation \\
\hline 21 & Racing & Splint on the left second metacarpal bone & $\begin{array}{l}\text { Fetlock problem and the medial side } \\
\text { of the left front }\end{array}$ \\
\hline 22 & Racing & Back pain; sacroiliac pain; pain on left hock palpation. & $\begin{array}{l}\text { Sacral Malalignments. Problem on left } \\
\text { hock and both stifles. }\end{array}$ \\
\hline 23 & Racing & Normal musculoskeletal evaluation & Normal evaluation \\
\hline
\end{tabular}




\section{DISCUSSION AND CONCLUSION}

The purchase evaluations were conducted in a methodical manner, as suggested by Beeman, Soule and Swanson (1992). Musculoskeletal system examination was a chosen system for comparison to the acupuncture palpation diagnosis because it is considered the most common cause of the purchaser deciding not to purchase a particular horse (GOBLE, 1992).

The agreement percentage (52.17\%) between both methods must be considered as the comparison of only the physical examination, which means palpation, excluding other important parts of a complete purchase evaluation in the way of a definitive picture of a horse condition. Considering that all the purchase evaluations presented comprehended history and observation previously and, ancillary diagnostic methods after, only 3 evaluations (horses number 6, 10 and 13) resulted very different on their conclusion. The horse number 8 evidenced topical blistering signs over the flexor tendons and had an ultrasonographic evaluation that would be conducted even if there were no suggestion from the acupuncture palpation diagnosis. Therefore, using both Musculoskeletal System Examination and Acupuncture Palpation Diagnosis as complementary methods, would enable to result in 20/23 (86.96\%) horses evaluated having a clear clinical condition.

Chinese Medicine sees the patient as a whole. Acupuncture Palpation Diagnosis has many meanings for a reactive point. Cain (2003b) has shown different combinations of reactive points that result in very specific diagnosis, of a joint problem or of another musculoskeletal system region, what he describes as syndromes. As the Chinese Medicine sees the individual as a whole, and many diagnostic points are localized on the horse's back (Back Shu Points) (CAIN, 2003a; FLEMING, 2001), being explained as somato-visceral reflex communications (CARNEIRO, 2003), conditions of other systems, not the musculoskeletal, are diagnosed using this method. Being so, the horses with a diagnosis of back pain from the musculoskeletal system examination, resulted in different diagnosis, most of them with a suggestion of a more specific problem, being a joint, region or a specific affected system.

A methodical purchase evaluation, integrating musculoskeletal system manipulation and acupuncture palpation diagnosis, results efficient, complete, rapid and flexible, as suggested by Beeman, Soule and Swanson (1992), with a more complete assessment of the horse condition (SUTHERLAND, 1997).

It can be concluded that, using Musculoskeletal System Examination together with Acupuncture Palpation Diagnosis as complimentary methods, by an experienced practitioner, for purchase evaluations, an $86,96 \%$ confidence for obtaining a clear clinical condition in the physical examination results, as part of a complete purchase trial.

\section{REFERENCE}

ALTAMIRANO, A. A. A. Examen pre compra de caballos deportivos o de recreo: un asunto de imágenes. Pets y Más, v. 1, n. 30, p. 40-41, 2001.

ASBURY, A. C. Medical evaluation of the reproductive system relevant to purchase. The Veterinary Clinics of North America: Equine Practice, Orlando, v. 8, n. 2, p. 395-412, 1992.

BEEMAN, G. M.; SOULE, S. G.; SWANSON, T. D. History and philosophy of the medical examination of horses for purchase. The Veterinary Clinics of North America: Equine Practice, Orlando, v. 8, n. 2, p. 257-266, 1992.

BENNETT, D. G. Medical examination of the digestive system relevant to purchase. The Veterinary Clinics of North America: Equine Practice, Orlando, v. 8, n. 2, p. 387-393, 1992.

CAIN, M. Hock syndrome In: Bioscan Inc., 2003a, p. 42-47.

Acupuncture diagnosis and treatment of the equine, $4^{\text {th. }} \mathrm{ed}$. 
CAIN, M. Sacral malalignments. In: $4^{\text {th }}$ ed. Bioscan Inc., 2003b, p.75-77.

Acupuncture diagnosis and treatment of the equine,

CAIN, M. Stifle syndrome In: Acupuncture diagnosis and treatment of the equine, $4^{\text {th }} \mathrm{ed}$. Bioscan Inc., 2003c, p. 36-42.

CARNEIRO, N. M. The biological mechanisms of acupuncture. In: INTERNATIONAL CONGRESS ON Veterinary ACUpunCture, 29., 2003, Santos. Proceedings... Santos: International Veterinary Acupuncture Society, 2003. p. 83-92.

FLEMING, P. Diagnostic acupuncture palpation examination in the horse. Veterinary Acupuncture: Ancient Art to Modern Medicine. $2^{\text {nd }}$ ed. Orlando, Florida: Mosby, 2001. p. 433-441, 2001.

FREGIN, G. F. Medical evalation of the cardiovascular system. The Veterinary Clinics of North America: Equine Practice, Orlando, v. 8, n. 2, p. 329-346, 1992.

GOBLE, D. O. Medical evaluation of the musculoskeletal system and common integument relevant to purchase. The Veterinary Clinics of North America: Equine Practice, Orlando, v. 8, n. 2, p. 285302, 1992.

HAWKINS, D. L. Purchase evaluation In: COLAHAN, P. T. et al. Equine medicine and surgery. 5. ed. Orlando: Mosby, 1999. p. 17-19. v. 1.

HAYNES, P. F. Examiantion of the upper and lower respiratory tract relevant to purchase. The Veterinary Clinics of North America: Equine Practice, Orlando, v. 8, n. 2, p. 347-364, 1992.

LAVACH, D. Medical evaluation of the eye relevant to purchase. The Veterinary Clinics of North America: Equine Practice, Orlando, v. 8, n. 2, p. 365-375, 1992.

McCORMICK, W. H. Oriental channel diagnosis in foot lameness of the equine forelimb. In: American Association of Equine Practitioners. Proceedings... v. 43, p. 330-332, 1997.

REED, S. The neurologic examiantion of the horse for purchase. The Veterinary Clinics of North America: Equine Practice, Orlando, v. 8, n. 2, p. 377-386, 1992.

SUTHERLAND, E.C. Integration of acupuncture and manipulation into a standard lameness examination and treatment approach. In: AMERICAN ASSOCIATION OF EQUINE PRACTITIONERS, 43, 1997. New Orleans. Proceedings... New Orleans, 1997. p. 319-321.

VONDERWELL, C. M. Practical use of acupuncture to diagnose and treat rear lameness in standardbreds.. In: AMERICAN ASSOCIATION OF EQUINE PRACTITIONERS. 43, 1997. New Orleans. Proceedings... New Orleans, p. 322-324. 1997.

Received in: 09/20/2006

Recebido em: 20/09/2006

Approved in: 03/30/2007

Aprovado em: 30/03/2007 